Int. J. Electrochem. Sci., 11 (2016) 3190 - 3205

International Journal of

ELECTROCHEMICAL

SCIENCE

$\underline{\text { www.electrochemsci.org }}$

\title{
Utilization of Waste Foundry Slag and Alccofine for Developing High Strength Concrete
}

\author{
Devinder Sharma ${ }^{1, *}$, Sanjay Sharma ${ }^{2}$, Ajay Goyal $^{3}$ \\ ${ }^{1}$ Research Scholar, I.K. Gujral Panjab Technical University, Kapurthala (Pb), India \& Associate \\ Professor, Baddi University of Emerging Sciences \& Technology, Baddi (HP), India. \\ ${ }^{2}$ Civil Engineering Department, National Institute of Technical Teachers Training and Research \\ Chandigarh, India. \\ ${ }^{3}$ Civil Engineering Department, Baddi University of Emerging Sciences and Technology, Baddi (HP), \\ India. \\ *E-mail: devinder.sharma@ baddiuniv.ac.in
}

doi: $10.20964 / 110403190$

Received: 12 January 2016 / Accepted: 14 February 2016 / Published: 1 March 2016

This paper discusses the strength development of concrete using Foundry Slag(FD) as partial replacement for conventional fine aggregates and Alccofine (AF) as partial replacement of cement. Concrete samples of M100 grade using water/binder ratio 0.239 , with varying percentage of FD ( 0 to $50 \%)$ and with optimum percentage of $\mathrm{AF}(15 \%)$ were casted and tested for compressive strength(CS), tensile strength(TS) and flexural strength(FS) development at the age of 7, 14, 28, 56 and 90 days. Replacement of fine aggregates with up to 45\% of FD showed an increase in CS, FS and TS at all ages but showed a decrease in these properties with $50 \%$ of FD. Results suggested that reasonably high strength concrete can be designed by substituting fine aggregates with $10 \%$ to $45 \%$ of FD and partial replacement of cement with $15 \%$ of Alccofine. Carbonation in terms of alkalinity test and Rapid Chloride Permeability Test had also been studied in the present research work. Result showed increase in alkalinity and improvement in permeability of concrete with increase in FD contents at optimized $(15 \%)$ replacement of Cement with Alccofine.

Keywords: Foundry Slag, Alccofine. High Strength Concrete, Compressive Strength, Flexural Strength, Tensile Strength, Carbonation, RCPT

\section{$\underline{\text { FULL TEXT }}$}

(C) 2016 The Authors. Published by ESG (www.electrochemsci.org). This article is an open access article distributed under the terms and conditions of the Creative Commons Attribution license (http://creativecommons.org/licenses/by/4.0/). 